\title{
Chronic trace metals effects of mine tailings on estuarine assemblages revealed by environmental DNA
}

\author{
Angelo F Bernardino ${ }^{\text {Corresp., }}{ }^{1}$, Fabiano M Pais ${ }^{2}$, Louisi S Oliveira ${ }^{1}$, Fabricio A Gabriel ${ }^{1}$, Tiago 0 Ferreira $^{3}$, Hermano \\ M Queiroz ${ }^{3}$, Ana Carolina A Mazzuco ${ }^{1}$ \\ ${ }^{1}$ Grupo de Ecologia Bentônica, Department of Oceanography, Universidade Federal do Espírito Santo, Vitoria, Espirito Santo, Brazil \\ 2 Instituto de Pesquisas René Rachou, FIOCRUZ/Minas Gerais, Belo Horizonte, Minas Gerais, Brazil \\ 3 Escola Superior de Agricultura Luiz de Queiroz, Universidade de São Paulo, Piracicaba, São Paulo, Brazil
}

Corresponding Author: Angelo F Bernardino

Email address: bernardino.ufes@gmail.com

Mine tailing disasters have occurred worldwide and contemporary release of tailings of large proportions raise concerns of the chronic impacts that trace metals may have on the aquatic biodiversity. Environmental metabarcoding (eDNA) offers an yet poorly explored opportunity for biological monitoring of impacted aquatic ecosystems from mine tailings and contaminated sediments. eDNA has been increasingly recognized to be an effective method to detect previously unrecognized small-sized Metazoan taxa, but their ecological responses to environmental pollution has not been assessed by metabarcoding. Here we evaluated chronic effects of trace metal contamination from sediment eDNA of the Rio Doce estuary, 1.7 years after the Samarco mine tailing disaster, which released over 40 million $\mathrm{m}^{3}$ of iron tailings in the Rio Doce river basin. We identified 123 new sequence variants (eOTUs) of benthic taxa and an assemblage composition dominated by Nematoda, Crustacea and Platyhelminthes; typical of other estuarine ecosystems. We detected environmental filtering on the meiofaunal assemblages and multivariate analysis revealed strong influence of Fe contamination, supporting chronic impacts from mine tailing deposition in the estuary. This was in contrast to environmental filtering of meiofaunal assemblages of non-polluted estuaries. Here we suggest that the eDNA metabarcoding technique provides an opportunity to fill up biodiversity gaps in coastal marine ecology and may become a valid method for long term monitoring studies in mine tailing disasters and estuarine ecosystems with high trace metals content. 
1 Chronic trace metals effects of mine tailings on

2 estuarine assemblages revealed by environmental

3 DNA

4

5

6

7

8

Angelo F. Bernardino ${ }^{1 *}$; Fabiano S. Pais ${ }^{2}$, Louisi S. Oliveira ${ }^{1}$; Fabricio A. Gabriel ${ }^{1}$, Tiago O. Ferreira $^{3}$, Hermano M. Queiroz ${ }^{3}$, Ana Carolina A. Mazzuco ${ }^{1}$

${ }^{1}$ Grupo de Ecologia Bentônica, Departamento de Oceanografia, Universidade Federal do Espírito Santo, Vitória, ES, 29057-570, Brazil, angelo.bernardino@ufes.br

${ }^{2}$ Instituto de Pesquisas René Rachou, FIOCRUZ/Minas Gerais, Belo Horizonte, Minas Gerais, Brazil

${ }^{3}$ Escola Superior de Agricultura Luiz Queiroz, Universidade de São Paulo, SP

Corresponding Author:

Angelo Bernardino

Av Fernando Ferrari, 514, Vitoria, Espirito Santo, 29075-910, Brazil

Email address: bernardino.ufes@gmail.com

\section{Abstract}

Mine tailing disasters have occurred worldwide and contemporary release of tailings of large proportions raise concerns of the chronic impacts that trace metals may have on the aquatic biodiversity. Environmental metabarcoding (eDNA) offers an yet poorly explored opportunity for biological monitoring of impacted aquatic ecosystems from mine tailings and contaminated sediments. eDNA has been increasingly recognized to be an effective method to detect previously unrecognized small-sized Metazoan taxa, but their ecological responses to environmental pollution has not been assessed by metabarcoding. Here we evaluated chronic effects of trace metal contamination from sediment eDNA of the Rio Doce estuary, 1.7 years after the Samarco mine tailing disaster, which released over 40 million $\mathrm{m}^{3}$ of iron tailings in the Rio Doce river basin. We identified 123 new sequence variants (eOTUs) of benthic taxa and an assemblage composition dominated by Nematoda, Crustacea and Platyhelminthes; typical of other estuarine ecosystems. We detected environmental filtering on the meiofaunal assemblages and multivariate analysis revealed strong influence of Fe contamination, supporting chronic impacts from mine tailing deposition in the estuary. This was in contrast to environmental filtering of meiofaunal assemblages of non-polluted estuaries. Here we suggest that the eDNA metabarcoding technique provides an opportunity to fill up biodiversity gaps in coastal marine ecology and may become a valid method for long term monitoring studies in mine tailing disasters and estuarine ecosystems with high trace metals content. 
40

41

42

43

44 Environmental assessment studies rely on accurate detection of biodiversity of an extremely 45 46

diverse and small-sized benthic fauna. For decades, morphological methods are the basis to impact assessment (IA) protocols at the cost of neglecting an enormous number of meiofaunal species that could not be accurately identified (Bhadury et al., 2006; Fonseca et al., 2010). There have been considerable advances in recent years by applying DNA-sequence based techniques, commonly referred as metabarcoding, to identify and quantify meiofaunal biodiversity (Creer et al., 2010; Bik et al. 2012; Brannock et al., 2014). Metabarcoding techniques can now be applied to access levels of richness and spatial patterns of diversity on marine Metazoans with use of homologous genes (nuclear 18S rRNA), and help uncover the extreme high biodiversity of meiofaunal benthic assemblages (Fonseca et al., 2010). These modern approaches offer fast assessments of marine Metazoan meiofaunal assemblages and are particularly useful for the identification of new species in areas with poorly reported biodiversity, which may be of special interest in IA studies.

Estuarine coastal ecosystems offer an opportunistic case to evaluate biodiversity-environmental relationships through environmental DNA (eDNA) since many estuaries are widely impacted by pollutants with deleterious effects to benthic assemblages (Lotze et al., 2006; Chariton et al., 2015; Hadlich et al., 2018; Lana and Bernardino, 2018). The Samarco mine tailing disaster that occurred in Brazil on November 2015, released near 43 million $\mathrm{m}^{3}$ of tailings in the Rio Doce river basin, which were transported for over $600 \mathrm{~km}$ until reaching the estuary and the Atlantic Ocean (Carmo et al., 2017; Magris et al., 2019). The tailings severely impacted the Rio Doce riverine and estuarine ecosystems causing rapid sediment accumulation, burial and death of 
65 benthic organisms, and rapidly (1-2 days) increased sediment heavy metal accumulation by

66 orders of magnitude from pre-impact conditions (Gomes et al., 2017). Although the released

67 tailings had trace metal concentrations that were within the Brazilian legislation (Segura et al.,

68 2016); the iron tailings deposited in the estuarine soils were heavily associated with trace metals

69 which are potentially bioavailable given the redox conditions of estuarine soils (Queiroz et al., 70 2018).

71 Trace metal accumulation in coastal ecosystems are reported to be highly associated with

72 changes in benthic assemblages and to increase human health risks due to potential

73 bioaccumulation in food webs (Venturini et al., 2002; Muniz et al., 2004; Rainbow, 2007;

74 Hauser-Davis et al., 2015). As a result, impact assessment studies that followed the Samarco

75 disaster were also based on traditional morphological biodiversity assessments (Gomes et al.,

76 2017). The potential chronic pollution effects in the Rio Doce estuary will likely demand long

77 term monitoring programs for this ecosystem. To that end, technical and taxonomic expertise

78 will be of key importance to monitor the estuarine biodiversity, but these efforts are typically

79 limited to the macrofaunal and megafaunal benthic taxa. Therefore, monitoring this

80 environmental disaster by increasing its biodiversity assessment to a broader range of cryptic and

81 meiobenthic taxa may bring valuable information on the extension of impacts.

82 In this study, we used an eDNA metabarcoding approach to evaluate the benthic biodiversity in

83 the Rio Doce estuary 1.7 years after the initial impacts of the Samarco disaster. We hypothesized

84 that spatial patterns of chronic metal contamination in the estuary would be significantly

85 associated with patterns of meiofaunal environmental taxonomic units (eOTUs), evidencing the

86 potential use of this technique for long term impact assessment of the estuary. We targeted

87 benthic meiofaunal eukaryote organisms by amplifying and sequencing the V9 hypervariable 
88 region of the $18 \mathrm{~S}$ ribosomal gene from purified eDNA. In addition, sediment variables (particle

89 size, organic carbon content) and trace metals concentrations were used to test for spatial

90 changes in benthic assemblages in response to contamination levels in the estuary.

91

92

93

94

95 Study site

96

97

110 Sample collection and DNA isolation

111 Environmental DNA was obtained from two biological replicates of estuarine undisturbed

112 surface $(0-5 \mathrm{~cm})$ sediments samples at 22 sites on the Rio Doce estuary in August 2017 (Figure 
113 1). The top $5 \mathrm{~cm}(\sim 300 \mathrm{~g}$ wet weight $)$ sediment was sampled with DNA-free sterile material and

114 immediately frozen in liquid nitrogen. In the laboratory, all glassware was cleaned and

115 autoclaved between samples to avoid cross contamination. Sediment samples were elutriated in

116 DNA-free material to concentrate benthic metazoans and eDNA was extracted following

117 protocols of Brannock and Halanych (2015), stored at $-20{ }^{\circ} \mathrm{C}$ and sent to the Genomic Services

118 Laboratory at Hudson Alpha Institute for Biotechnology (Huntsville, Alabama) for

119 metabarcoding sequencing. Briefly, the total DNA from $200 \mathrm{~g}$ (ww) of frozen sediments were

120 extracted from each replicate separately with a Mobio PowerSoil(R) kit according to

121 manufacturer's protocol with a 2 min bead-beating step. DNA integrity was evaluated using

122 electrophoresis on 1\% agarose gels and DNA purity was assessed with a NanoDrop

123 spectrophotometer (Thermo Fisher Scientific Inc., Waltham, MA, USA). Accurate DNA

124 quantification was obtained using a Qubit ${ }^{\circledR}$ 3.0 Fluorometer (Life Technologies-Invitrogen,

125 Carlsbad, CA, USA). Only 20 stations had enough bulk DNA after extraction and 7 samples out

126 of the expected 40 replicates did not yield high quantities of purified eDNA. In total 33 sediment

127 eDNA samples from the Rio Doce estuary were then submitted to amplicon library preparation

128 and Illumina sequencing (Table 1).

129 Sediment samples were obtained for trace metals, grain size and total organic matter analysis and

130 frozen $\left(-20^{\circ} \mathrm{C}\right)$. Grain size was analyzed by sieving and pipetting techniques (Suguio, 1973).

131 Total Organic Matter (TOM) content was quantified gravimetrically as the weight loss after

132 combustion $\left(500^{\circ} \mathrm{C}\right.$ for $\left.3 \mathrm{~h}\right)$. In each station, metal contamination was evaluated from two

133 independent replicate samples. For the total trace metal contents, $\sim 1 \mathrm{~g}$ of dry sediment samples

134 were digested by an acid mixture $\left(\mathrm{HCl}+\mathrm{HNO}_{3}+\mathrm{HF}\right.$; USEPA, 1996) in a microwave digestion

135 system. Following digestion, concentrations of trace metals (Al, Ba, Cr, As, Fe, Zn, Mn, Pb, Cd, 
$136 \mathrm{Co}$ ) in all samples were determined using an inductively coupled plasma optical emission

137 spectroscopy (ICP-OES; Thermo Scientific - iCAP 6200).

138

139 Illumina sequencing and bioinformatic pipelines

140 eDNA samples were sent to the Genomic Services Laboratory at Hudson Alpha Institute for

141 Biotechnology (Huntsville, Alabama) for amplicon sequencing. The Eukaryotic-specific V9

142 hypervariable region of 18S SSU rRNA gene was amplified using primers Illumina_Euk_1391f

143 forward primer [GTACACACCGCCCGTC] and Illumina_EukBr reverse primer

144 [TGATCCTTCTGCAGGTTCACCTAC] (Caporaso et al., 2010). The V9 region has been

145 previously has been shown to be accurately identify eukaryotes from environmental samples and

146 has an amplicon length suited to most commercially available Illumina platforms (Amaral-

147 Zettler et al., 2009; Brannock and Halanych 2015). Library size distribution was accessed using

148 a 2100 Bioanalyzer (Agilent, Santa Clara, CA, USA). Amplicons were sequenced on MiSeq

149 (Illumina, San Diego, CA, USA) using the Reagent Kit v3 (300bp PE).

150 Demultiplexed raw single-end reads for each sample were processed and analyzed using the

1512018.8 distribution of the QIIME2 software suite to estimate the observed taxa across replicates

152 (Bolyen et al., 2018). Fastq files were first imported as QIIME2 artifacts with the appropriate

153 import plugin. Single-end reads were then denoised via DADA2 (Callahan et al., 2016) with the

154 dada2 denoise-single plugin, where the --p-trunc parameter was set to 270 to remove low-quality

155 bases and the --p-trim was set to 20 to remove primer sequence. The taxonomic composition of

156 the amplicon sequence variants, generated after running the dada2 plugin, were assigned using

157 the machine learning Python library scikit-learn (Pedregosa et al., 2011). A pre-trained Naïve

158 Bayes classifier, trained on Silva 132 database (Quast et al., 2013) clustered at $99 \%$ similarity, 
159 was downloaded from QIIME2 website [https://docs.qiime2.org/]. The feature-classifier plugin

160 was used to generate de classification results, and the taxonomic profiles of each sample were

161 visualized using the taxa barplot plugin.

162

163 Statistical analysis

164 Only Metazoan variant calls were selected for ecological analysis. Comparisons of community 165 composition were based on replicate averages of eOTU reads from benthic taxonomic groups. Benthic taxa were grouped for taxonomic comparisons into main taxa including Gastrotricha,

167 168 169 170 Platyhelminthes, Nematoda, Annelida, Crustacea, Mollusca and Cnidaria. Other invertebrate taxa including Gnathostomulida, Micrognathozoa, Tardigrada, Rotifera and Bryozoa were grouped into "Other invertebrates". Unassigned or other taxa (e.g. Insecta) were represented as "Other Metazoa". Taxonomic (eOTUs) accumulation curves (Chao1) were compared across datasets by using: i. full eOTU matrices (Table S1), ii. dominant eOTUs with over $0.1 \%$ of total Metazoan reads (Table S2); and iii) the baseline benthic morphological diversity from the Rio Doce estuary (Gomes et al., 2017). Chao 1 curves were based on presence-absence eOTU matrices integrated between replicates from each station and were estimated in Primer-e V6 (Clarke and Gorley, 2006).

The spatial consistency of metal contamination with benthic assemblage composition was tested with a Canonical Analysis of Principal coordinates (CAP; Anderson and Willis, 2003) complemented with multidimensional scaling (Anderson, 2001; McArdle \& Anderson, 2001; Oksanen et al., 2018). Before the CAP analysis was run, the existence of highly correlated variables (trace metals) was assessed and trace metals with significant correlation with Fe contents were removed. The resulting multivariate analysis was only run with sediment contents 
182 of $\mathrm{Fe}, \mathrm{As}$ and $\mathrm{Pb}$, given their non-significant auto-correlations (Table $\mathrm{S} 3$ ). In addition, these trace

183 metals (Fe and $\mathrm{Pb}$ ) markedly increased (5 to 20-fold) in concentration with the impact (Gomes et

184 al., 2017) and were often above the recommended limits within the Brazilian legislation (Guerra

185 et al., 2017). Given that the concentration of other trace metals were highly correlated with Fe,

186 Fe contents likely represent the overall effect of mine tailings deposited in the estuary (Queiroz

187 et al., 2018).

188 The CAP was run based on presence or absence matrices with full Metazoan eOTUs and with the 189 reduced assemblage composed of dominant reads $(>0.1 \%$ of reads; Table S2). The CAP eOTU 190 matrices were then compared with environmental (trace metal concentrations, sediment OM, \% 191 sand and salinity) spatial patterns based on Euclidean distances matrix to determine vectors that 192 contributed to differences among samples (Mazzuco et al., 2019). Graphical and analytical 193 processing were performed in R project (R Core Team, 2016) with the packages: 'stats' and 194 'vegan' (Oksanen et al., 2018).

195

196

197

198

199

200

201

202

203

204 205 206

\section{Results}

The Rio Doce estuary exhibited low salinities at the time of sampling (0.1 to 3.7). Sediments were dominated by sand particles ( $>62 \%$ sand), with the exception of site 2 which showed less sand-sized particles (12\%; Table 1). Sediment total organic matter (TOM) varied from 1.5 to $16.8 \%$, with the highest organic content at stations 3,13 and $22(16.8,13.8$ and $10.2 \%$;

respectively). Several estuarine areas had TOM in a similar range of 2 to $6.2 \%$ (Table 1), and sediment organic content was significantly correlated to Fe content (Pearson $r=0.5043, p=$ 0.023; Table S4). The concentration of trace metals in the estuarine sediments also varied markedly along the studied area (Table 1). Fe concentrations ranged from 18,814 to 54,982 
207 mg.kg-1 and were highly correlated with several other trace metals including $\mathrm{Al}, \mathrm{Cd}, \mathrm{Cr}, \mathrm{Co}, \mathrm{Cu}$, 208 Mn and Zn (Table S3; Table S5).

209 We obtained a total of 9,836,039 sequence reads, of which $6,840,886$ were of high quality. The 210 number of sequence reads per station ranged from 35,915 (St 16) to 359,718 (St 4), with an 211 average of 207,285 total sequence variants per station. Stations that had only one replicate 212 sequenced had a lower (e.g. stations 14 and 16) or a similar number of reads (e.g. stations 19 and 21320 ) of sites that had two replicates sequenced. On average, 55.4\% of reads corresponded to 214 aquatic or marine Metazoan taxa (Table S1). The eOTU richness per station ranged over three215 fold from 16 to 54 eOTUs (Table 1). Assemblages were dominated by Nematoda (34 eOTUs), 216 Platyhelminthes (19), Crustacea (18), Gastrotricha and Annelida (12 eOTUs each; Table S1; 217 Figure 2). Most sites had over $80 \%$ of sequence variant reads represented by two to three 218 meiofaunal taxa, including the dominant Gastrotricha, Nematoda and Crustacea. The number of 219 unassigned Metazoan taxa was large (> 50\%) at stations 16 and 17; whereas it remained less than $22020 \%$ in most sites.

221 The eDNA species accumulation curves did not reach an asymptote with addition samples 222 suggesting an yet incomplete biodiversity characterization of the estuary (Figure 3). Several 223 eOTUs $(\mathrm{N}=88)$ were represented by less than $0.1 \%$ of sequence variant reads. When we removed 224 the eOTUs that had less than $0.1 \%$ of sequence reads, the species accumulation stabilized at 32 225 eOTUs with 5 to 7 samples, with no additional gain of taxa. The species accumulation asymptote 226 with dominant eOTUs was reached in about half the number of samples necessary in morphology-based studies (12 to 14 samples; Figure 3). The number of meiofaunal eOTUs 228 (eOTU richness) were largely uncorrelated to sediment grain size $(p=0.161), \mathrm{Fe}(p=0.647)$ and 229 organic matter content ( $p=0.6395$; Table S4; Figure 4). 
230 The multivariate patterns of dominant meiofaunal $(\mathrm{S}=32)$ eOTU composition were significantly 231 related to $\mathrm{Fe}$ contents in sediments $(\mathrm{F}=2.89, p=0.018$, Figure 5; Table 2). The CAP axes 1 and 2 232 explained $44 \%$ and $21 \%$ of multivariate variability; respectively (Table 2 ). Fe contents in 233 sediments was associated to the multivariate distribution of meiofaunal eOTUs including the 234 Nematoda Mesodorylaimus nigritulus and Epitobrilus stefanskii, Harpacticoid copepods, the 235 Platyhelminthes Cirrifera dumosa and Bothrioplana sinensis, and Ostracods (Chrissia 236 dongqianhuensis). Monhysteridae and Desmodorida spp. nematode worms were negatively correlated to Fe concentrations (CAP1 score $=-0.25$ to -0.18$). \mathrm{Pb}$ and As contamination were not correlated to Fe concentrations in sediments and were not significantly associated with the meiofaunal multivariate composition (Table 2).

\section{Discussion}

243

244 Our study demonstrates that environmental DNA can be an effective method to indicate chronic 245 contamination effects on benthic assemblages of the Rio Doce estuary, supporting our 246 hypothesis. This first eDNA survey in the Rio Doce estuary also revealed a previously 247 unrecognized benthic biodiversity, even with significant impacts by trace metal levels 1.7 years 248 after the initial impacts. Although there is no baseline eDNA assessment from the Rio Doce 249 estuary, the impacted sediments potentially supported over 32 dominant meiofaunal taxa 250 (eOTUs), with a spatial distribution significantly related to Fe (and correlated metals) 251 contamination.

252 The Rio Doce eDNA composition was similar to other estuarine and marine sediments assessed 253 by metabarcoding methods (Fonseca et al., 2010; Faria et al., 2018). Nematoda, Gastrotricha and 254 Crustaceans were highly dominant in the estuary with local changes in relative abundance across 
255 sites sampled. The marked spatial variability in assemblage composition within the estuary

256 indicates that benthic assemblages were spatially structured; which is a similar pattern commonly

257 observed in morphology-based assessments. Environmental filtering in benthic assemblages may

258 result from a combination of sediment and water variables, with grain size, salinity and food

259 availability being critical to species turnover and replacement in estuarine benthos (Menegotto et

260 al., 2019). Although our study design does not allow for an hierarchical spatial analysis of

261 variables that determined the observed environmental filtering, the detection of spatial variance

262 in assemblages from eDNA samples suggests that the biodiversity assessment is likely

263 representing living benthic organisms instead of predominantly ancient or allochthone DNA.

264 There is now strong evidence supporting that eDNA techniques can detect complex spatial

265 variability in estuarine and coastal marine ecosystems (Chariton et al., 2015; Faria et al., 2018);

266 and our data additionally supports its use to biodiversity assessment in a heavily impacted

267 estuary.

268 Most eOTUs represented new occurrences for the estuary, but yet with several unassigned taxa,

269 stressing the complementarity value of molecular and morphological approaches to ecological

270 and impact assessment studies (Leasi et al., 2018). We recovered a total of 123 environmental

271 OTUs (eOTUs) in the Rio Doce estuarine sediments, increasing by over 20 -fold the previous

272 richness of benthic taxa based on morphological identifications (Gomes et al., 2017). The species

273 accumulation curves did not reach an asymptote with addition of eDNA samples, and most

274 eOTUs $(\mathrm{N}=88)$ were represented by less than $0.1 \%$ of sequence variant reads, suggesting an yet

275 incomplete biodiversity assessment of the Rio Doce estuary even with high levels of trace

276 metals. However, estuaries are highly connected to continental and marine ecosystems and it is

277 unlikely that species accumulation curves would reach an asymptote with a single biodiversity 
278 assessment (Chariton et al., 2015; Nascimento et al., 2018). The rapid increase and stabilization

279 of the number of dominant meiofaunal OTUs with the addition of new samples suggests a

280 reasonable beta-diversity assessment of the Rio Doce estuary with the effort taken. Sites that had

281 only one sequenced replicate due to low DNA stocks attained similar or lower OTUs richness if 282 compared to other stations, but the sediment volumes used in this study $(>200 \mathrm{~g})$ were well over

283 the necessary to avoid technical bias in the detection of Metazoan diversity (Brannock and

284 Halanych, 2015; Nascimento et al., 2018).

285 This single eDNA survey was efficient in assembling benthic meiofaunal assemblages in the Rio 286 Doce estuary. The species accumulation curves indicate that half of the sampling effort would be 287 necessary to characterize the dominant meiofaunal groups in the estuary if compared to the 288 species accumulation rate of previous morphological assessments. eDNA metabarcoding can be 289 more efficient at characterizing marine taxa (Lobo et al., 2017), and our data supports its use on 290 long term studies where taxonomic and technical limitations cannot be controlled (Bista et al., 291 2017). The lack of controlled methods may be a crucial problem to the biodiversity monitoring 292 that followed the Samarco disaster on the Rio Doce, given the extremely large scale and diversity 293 of impacted ecosystems. It is estimated that over 2,000 ha of terrestrial, limnetic and estuarine 294 ecosystems along the Rio Doce basin were directly impacted by the disaster (Carmo et al., 2017); 295 with additional potential effects on nearby coastal zones (Magris et al., 2019). Given the large 296 area, the diversity and natural complexity of ecosystems to be monitored, it is likely that the 297 number of biological samples needed to reach reasonable statistical power to detect biodiversity 298 impacts would be prohibitive (Fairweather, 1991). Therefore, the massive amount of data 299 obtained in metabarcoding techniques could have a profound contribution to environmental 
300 monitoring in this scenario, which would also increase dramatically the discovery of cryptic 301 species on a range of aquatic and terrestrial ecosystems.

302 Multivariate analysis revealed that Fe contents (and other correlated metals) are partially

303 structuring spatial patterns of dominant benthic meiofaunal assemblages in the Rio Doce estuary

3041.7 years after the disaster. The sediment $\mathrm{Fe}$ contents were significant predictors of changes in

305 dominant meiofaunal eOTUs including nematodes, copepods, ostracods and flatworms. These

306 groups corresponded to over $2 / 3$ of meiofaunal OTUs in the estuary and revealed that trace metal

307 contents are driving spatial patterns of the Rio Doce estuarine biodiversity. Our data suggest that

308 benthic assemblages were highly sensitive to chronic metal contamination in polluted estuaries,

309 and partially explains a lower effect of sediment grain size and organic matter on local

310 meiofauna (e.g. Faria et al., 2018; Menegotto et al., 2019). This could indicate that the Rio Doce

311 estuarine assemblages were strongly impacted after the disaster through the exclusion of

312 intolerant species, although we lack baseline eDNA to fully support that hypothesis.

313 The extremely high Fe contents allied to covariance of several potentially toxic trace metals that

314 are adhered to iron oxides present in the tailings strongly suggest that the tailings have led to

315 major changes in the estuarine benthic biodiversity since the initial impact (Queiroz et al., 2018).

316 The Rio Doce basin was previously polluted by historical mining and urban activities, so the

317 trace metals that rapidly accumulated in the estuary were likely transported downstream attached

318 to Fe oxides from the released tailings. The initial impacts in the Rio Doce estuary were

319 observed immediately with the arrival of tailings, which led to significant (2-20 times) increases

320 in sediment $\mathrm{Fe}, \mathrm{Mn}, \mathrm{Cr}, \mathrm{Ni}, \mathrm{Cu}, \mathrm{Zn}$ and As (Gomes et al., 2017). Sediment concentrations of $\mathrm{Fe}$,

$321 \mathrm{~Pb}$ and selected trace metals in the Rio Doce in August 2017 continued to be 2-20 times higher

322 compared to preserved (Piraquê-Açu-Mirim estuary) or polluted estuaries such as the Vitoria 
323 Bay, located in a major metropolitan and industrial area $\sim 100 \mathrm{~km}$ to the south (Hadlich et al., 324 2018).

325 The statistical lack of $\mathrm{As}$ and $\mathrm{Pb}$ effects on the multivariate distribution and composition of 326 meiofaunal assemblages have important implications for future environmental monitoring in the 327 estuary. One plausible cause is that not all elements that are accumulated in the sediments are 328 bioavailable and have toxicity to the estuarine biota. Given the amplitude of trace metals 329 accumulated in the Rio Doce sediments since the mining tailing impacts that occurred in 2015, it 330 is very likely that a combination of these contaminants lead to further changes in the estuarine 331 benthos. The sediment concentrations of $\mathrm{Pb}$ in August 2017 were over 20 times higher than 332 baseline values (Gomes et al., 2017); and several other trace metals also increased with time 333 since the impact. Queiroz et al. (2018) reported a significant correlation between $\mathrm{Fe}, \mathrm{Pb}$ and 334 other trace metals in tailing deposits after the initial impacts in the Rio Doce estuary in 2015. The 335 iron oxides from tailings deposited in the estuary have a strong capacity of metal retention 336 (Cornell and Schwertmann 2003; Yin et al. 2016); and they are likely to be released due 337 dissimilatory iron reduction under estuarine conditions (Bonneville et al. 2009; Queiroz et al., 338 2018; Xia et al. 2019). Although anoxic estuarine soils favor the formation of sulfides (e.g. 339 Pyrite; AVS) which have strong affinity and role in the chelation of metals (Machado et al., 340 2010; Nóbrega et al., 2013), the Rio Doce estuary contrast to several other estuaries due to low 341 salinity, low tidal influence and an apparent limited sulfate availability and sulfate reduction that 342 reduce the formation of sulfides (Queiroz et al., 2018). As a result, the observed relationship of 343 meiofaunal assemblages with Fe contents (and other trace metals) suggest that the tailings have 344 some toxicity to benthic organisms even though a number of contaminants may not achieve 345 alarming concentrations. 
346 The effects of trace metal contents on the Rio Doce benthic assemblages resemble impacts in

347 other areas that are highly polluted with trace metals, but these effects could be confounded with

348 the constant environmental changes that typically occur in these ecosystems (Krull et al., 2014;

349 Martins et al., 2015). Our approach of selecting dominant meiofaunal OTUs to multivariate

350 analysis led to positive detection of Fe contents effects and associated trace metals. This

351 approach was justifiable given that we detected 88 eOTUs with less than $0.1 \%$ of sequence

352 variant reads, which could be potentially associated with allochthone DNA from connected river

353 or ocean ecosystems and would not be under influence of local contaminants. The use of

354 indicator taxa or functional groups to eDNA biodiversity assessment studies is becoming practice

355 in ecological studies (e.g. Bista et al., 2017) and our approach offers an important

356 methodological approach for detection of trace metals effects in aquatic biota that need to be

357 further investigated in other case studies.

358

359 Conclusions

360

361 In conclusion, our eDNA survey of benthic meiofaunal assemblages in the Rio Doce estuary

362 detected environmental filtering with strong influence of contamination by Fe and other

363 correlated trace metals, supporting chronic mine tailing impacts in the estuary. Our study is also

364 in agreement with previous assertions that ecological inferences from eDNA analysis may

365 increase the performance of biodiversity assessments in marine ecosystems by capturing a range

366 of cryptic taxa, thus greatly improving current short and long-term impact assessment studies.

367 The use of eDNA to the Samarco mine tailing disaster would benefit monitoring assessments

368 with standard techniques and dramatically increase our knowledge of the biodiversity of cryptic

369 aquatic species. The continued sampling and monitoring would also increase the precision of the

370 eDNA assessments, especially if allied to detailed morphological work. 
371

372

373

374

375

376

377

378

379

380

381

382

383

384

385

386

387

388

389

390

391

392

393

394

395

396

397

\section{Acknowledgements}

We thank students that helped on field sampling.

\section{References}

Amaral-Zettler LA, McCliment EA, Ducklow HW, Huse SM. 2009. A Method for Studying Protistan Diversity Using Massively Parallel Sequencing of V9 Hypervariable Regions of Small-Subunit Ribosomal RNA Genes. PLoS ONE 4(7): e6372.

https://doi.org/10.1371/journal.pone.0006372

Anderson MJ. 2001. A new method for non-parametric multivariate analysis of variance. Austral Ecology 26, 32-46. doi: 10.1111/j.1442-9993.2001.01070.pp.x

Anderson MJ, Willis TJ. 2003. Canonical analysis of principal coordinates: a useful method of constrained ordination for ecology. Ecology 84, 511-525.

Bernardino AF, Pagliosa PR, Christofoletti RA, Barros F, Netto SA, Muniz P, Lana PC. 2016. Benthic estuarine communities in Brazil: moving forward to long term studies to assess climate change impacts. Brazilian Journal of Oceanography, 64(sp2): 83-97. http://dx.doi.org/10.1590/S1679-875920160849064sp2

Bernardino AF, Azevedo ARB, Pereira Filho ACD, Gomes LEO, Bissoli LB, Barros FCR. 2018. Benthic Estuarine Assemblages of the Eastern Marine Brazilian Ecoregion. In: Brazilian Estuaries: a benthic perspective. Lana, P.C. and Bernardino, A.F. (eds). Springer International Publishing. Pgs 95-116. 212pp. 
398 Bik HM, Porazinska DL, Creer S, Caporaso, JG, Knight R, Thomas WK, 2012b. Sequencing our 399 way towards understanding global eukaryotic biodiversity. Trends in Ecology and Evolution $400 \quad 27,233-243$.

401 Bissoli LB, Bernardino AF. 2018. Benthic macrofaunal structure and secondary production in 402 tropical estuaries on the Eastern Marine Ecoregion of Brazil. PeerJ 6:e4441; DOI $403 \quad 10.7717 /$ peerj.4441

404 Bista I, Carvalho GR, Walsh K, Seymour M, Hajibabaei M, Lallias D, Christmas M, Creer S. 405 2017. Annual time-series analysis of aqueous eDNA reveals ecologically relevant dynamics 406 of lake ecosystem biodiversity. Nature Communications 8: 14087. 10.1038/ncomms14087 407 Bhadury P, Austen MC, Bilton DT, Lambshead PJD, Rogers AD, Smerdon GR. 2006.

408 Development and evaluation of a DNA-barcoding approach for the rapid identification of 409 nematodes. Marine Ecology Progress Series 320: 1-9. https://doi.org/10.3354/meps320001

410 Bolyen E, Rideout JR, Dillon MR, Bokulich NA, Abnet C, Al-Ghalith GA, Alexander H, Alm 411 EJ, Arumugam M, Asnicar F, Bai Y, Bisanz JE, Bittinger K, Brejnrod A, Brislawn CJ, 412 Brown CT, Callahan BJ, Caraballo-Rodriguez AM, Chase J, Cope E, Silva R, Dorrestein PC, 413 Douglas GM, Durall DM, Duvallet C, Edwardson CF, Ernst, M, Estaki M, Fouquier J, 414 Gauglitz, JM, Gibson DL, Gonzalez A, Gorlick K, Guo J, Hilman B, Holmes S, Holste H, 415 Huttenhower C, Huttley G, Janssen S, Jarmusch AK, Jiang L, Kaehler B, Kang KB, Keefe 416 CR, Keim P, Kelley ST, Knights D, Koester I, Kosciolek T, Kreps J, Langille MG, Lee J, 417 Ley R, Liu Y, Loftfield E, Lozupone C, Maher M, Marotz C, Martin BD, McDonald D, 418 McIver LJ, Melnik AV, Metcalf JL, Morgan SC, Morton J, Naimey AT, Navas-Molina JA, 419 Nothias LF, Orchanian SB, Pearson T, Peoples SL, Petras D, Preuss ML, Pruesse E, 420 Rasmussen LB, Rivers A, Robeson, II MS, Rosenthal P, Segata N, Shaffer M, Shiffer A, 
421

422

423

424

425

426

427

428

429

430

431

432

433

434

435

436

437

438

439

440

441

442

Sinha R, Song SJ, Spear JR, Swafford AD, Thompson LR, Torres PJ, Trinh P, Tripathi A, Turnbaugh PJ, Ul-Hasan S, van der Hooft JJ, Vargas F, Vázquez-Baeza Y, Vogtmann E, von Hippel M, Walters W, Wan Y, Wang M, Warren J, Weber KC, Williamson CH, Willis AD, Xu ZZ, Zaneveld JR, Zhang Y, Zhu Q, Knight R, Caporaso JG. 2018. QIIME 2:

Reproducible, interactive, scalable, and extensible microbiome data science. PeerJ Preprints 6:e27295v2. https://doi.org/10.7287/peerj.preprints.27295v2

Bonneville S, Behrends T, Van Cappellen P. 2009. Solubility and dissimilatory reduction kinetics of iron(III) oxyhydroxides: A linear free energy relationship. Geochimica et Cosmochimica Acta 73, 5273-5282. https://doi.org/10.1016/j.gca.2009.06.006

Brannock P, Waits DS, Sharma J, Halanych KM. 2014. High-Throughput Sequencing Characterizes Intertidal Meiofaunal Communities in Northern Gulf of Mexico (Dauphin Island and Mobile Bay, Alabama). Biological Bulletin 227: 161-174

Brannock P, Halanych KM. 2015. Meiofaunal community analysis by high-throughput sequencing: Comparison of extraction, quality filtering, and clustering methods. Marine Genomics 23: 67-75

Callahan BJ, McMurdie PJ, Rosen MJ, Han AW, Johnson AJ, Holmes SP. 2016. DADA2: Highresolution sample inference from Illumina amplicon data. Nature Methods 13: 581-583.

\section{https://doi.org/10.1038/nmeth.3869}

Caporaso JG, Kuczynski J, Stombaugh J, Bittinger K, Bushman FD, Costello EK, Fierer N, Pena AG, Goodrich JK, Gordon JI, Huttley GA, Kelley ST, Knights D, Koenig JE, Ley RE, Lozupone CA, McDonald D, Muegge, BD, Pirrung M, Reeder J, Sevinsky JR, Turnbaugh PJ, Walters WA, Widmann J, Yatsunenko T, Zaneveld J, Knight R. 2010. QIIME allows 
443

444

445

446

447

448

449

450

451

452

453

454

455

456

457

458

459

460

461

462

463

464

analysis of high-throughput community sequencing data. Nature Methods 7: 335-336. https://doi.org/10.1038/nmeth.f.303

Carmo FF, Kamino LHY, Junior RT, Campos IC, Carmo FF, Silvino G, Castro KJ, Mauro ML, Rodrigues N, Miranda M, Pinto CEF. 2017. Fundao tailings dam failures: the environment tragedy of the largest technological disaster of Brazilian mining in global context. Persperctives in Ecology and Conservation 15: 145-151.

Chariton AA, Stephenson S, Morgan MJ, Steven ADL, Colloff MJ, Court LN, Hardy CM. 2015. Metabarcoding of benthic eukaryote communities predicts the ecological condition of estuaries. Environmental Pollution 203: 165-174.

http://dx.doi.org/10.1016/j.envpol.2015.03.047

Clarke KR, Gorley RN. 2006. PRIMER v6: User Manual/Tutorial. PRIMER-E, Plymouth, pp. 192.

Cornell RM, Schwertmann U. 2003. The Iron Oxides: Structure, Reactions, Occurences and Uses, WILEY-VCH. https://doi.org/10.1002/3527602097.ch1

Creer S, Fonseca VG, Porazinska DL, Giblin-Davis RM, Sung W, Power DM, Packer M, Carvalho GR, Blaxter ML, Lambshead PJD, Thomas WK. 2010. Ultrasequencing of the meiofaunal biosphere: practice, pitfalls and promises. Molecular Ecology: 19, 4-20.

Faria LC, Di Domenico M, Andrade SCS, Santos MC, Fonseca G, Zanol J, Amaral ACZ. 2018. The use of metabarcoding for meiofauna ecological patterns assessment. Marine Environmental Research 140: 160-168. https://doi.org/10.1016/j.marenvres.2018.06.013 Fairweather PG. 1991. Statistical power and design requirements for environmental monitoring. Australian Journal of Marine and Freshwater Research 42: 555-567 
465 Fonseca VG, Carvalho GR, Sung W, Johnson HF, Power DM, Neill SP, Packer M, Blaxter ML, 466 Lambshead, PJD, Thomas, WK, Creer S. 2010. Second-generation environmental sequencing 467 unmasks marine metazoan biodiversity. Nature Communications 1: 98.

$468 \quad$ http://dx.doi.org/10.1038/ncomms1095.

469 Gomes LEO, Correa LB, Sa F, Neto RR, Bernardino AF. 2017. The impacts of the Samarco 470 mine tailing spill on the Rio Doce estuary, Eastern Brazil. Marine Pollution Bulletin 120, 28471 36. https://doi.org/10.1016/j.marpolbul.2017.04.056.

472 Guerra MBB, Teaney BT, Mount BJ, Asunskis DJ, Jordan BT, Barker RJ, Santos EE, Schaefer 473 CEGR. 2017. Post-catastrophe Analysis of the Fundão Tailings Dam Failure in the Doce 474 River System, Southeast Brazil: Potentially Toxic Elements in Affected Soils. Water, Air \& 475 Soil Pollution 228:252. Doi: 10.1007/s11270-017-3430-5

476 Hadlich HL, Venturini N, Martins CC, Hatje V, Tinelli P, Gomes LEO, Bernardino AF. 2018. 477 Multiple biogeochemical indicators of environmental quality in tropical estuaries reveal 478 contrasting conservation opportunities. Ecological Indicators 95: 1, 21-31.

$479 \quad$ https://doi.org/10.1016/j.ecolind.2018.07.027.

480 Hauser-Davis RA, Gonçalves RA, Ziolli RL, Campos RC. 2015. A novel report of 481 metallothioneins in fish bile: SDS-PAGE analysis, spectrophotometry quantification and 482 metal speciation characterization by liquid chromatography coupled to ICP-MS. Aquatic 483 Toxicology 116-117: 54-60.

484 Krull M, Abessa DMS, Hatje V, Barros F. 2014. Integrated assessment of metal contamination in 485 sediments from two tropical estuaries. Ecotoxicology and Environmental Safety 106: 195486203. 
487 Lana PC, Bernardino AF. 2018. Brazilian Estuaries: A benthic perspective. Springer

488 International Publishing. In: Brazilian Marine Biodiversity Series. Turra, A. (Ed.). ISSN

489 2520-1085, ISBN 978-3-319-77779-5. DOI: 10.1007/978- 3-319-77779-5

490 Lobo J, Shokrallia S, Costa MH, Hajibabaei M, Costa FO. 2017. DNA metabarcoding for high491 throughput monitoring of estuarine macrobenthic communities. Scientific Reports 7: 15618

492 Leasi F, Sevigny JL, Laflamme EM, Artois T, Curini-Galletti M, Navarrete AJ, Di Domenico M, 493 Goetz F, Hall JA, Hochberg H, Jorger KM, Jondelius U, Todaro MA, Wirshing HH, 494 Norenburg JL, Thomas WK. 2018. Biodiversity estimates and ecological interpretations of 495 meiofaunal communities are biased by the taxonomic approach. Communications Biology

Magris RA, Marta-Almeida M, Monteiro JAF, Ban NC. 2019. A modelling approach to assess 506

507

Machado W, Villar LS, Monteiro FF, Viana LCA, Santelli RE, 2010. Relation of acid-volatile sulfides (AVS) with metals in sediments from eutrophicated estuaries: Is it limited by metalto-AVS ratios? Journal of Soils and Sediments 10, 1606-1610. https://doi.org/10.1007/s11368-010-0297-0 the impact of land mining on marine biodiversity: Assessment in coastal catchments experiencing catastrophic events (SW Brazil). Science of the Total Environment 659: 828840. https://doi.org/10.1016/j.scitotenv.2018.12.238 
509 Martins MVA, Silva F, Laut LLM, Frontalini F, Clemente IMM, Miranda P, Figueira R, Souza

510 SHM, Dias JMA. 2015. Response of Benthic Foraminifera to Organic Matter Quantity and

511 Quality and Bioavailable Concentrations of Metals in Aveiro Lagoon (Portugal). Plos One

512 10(2): e0118077. https://doi.org/10.1371/journal.pone.0118077

513 Mazzuco ACA, Stelzer PS, Donadia G, Bernardino JV, Joyeux J-C, Bernardino AF 2019. Lower

514 diversity of recruits in coastal reef assemblages are associated with $\mathrm{T}$ higher sea temperatures

515 in the tropical South Atlantic. Marine Environmental Research 148: 87-98. Doi:

$516 \quad$ 10.1016/j.marenvres.2019.05.008

517 McArdle BH, Anderson MJ. 2001. Fitting Multivariate Models to Community Data: A Comment 518 on Distance-Based Redundancy Analysis. Ecology 82: 290-297.

519 Menegotto A, Dambros CS, Netto SA. 2019. The scale-dependent effect of environmental filters 520 on species turnover and nestedness in an estuarine benthic community. Ecology 100 (7):

$521 \quad$ e02721. Doi: 10.1002/ecy.2721

522 Muniz P, Danulat E, Yannicelli B, Garcia-Alonso J, Medina G, Bicego MC 2004. Assessment of 523 contamination by heavy metals and petroleum hydrocarbons in sediments of Montevideo 524 Harbour (Uruguay). Environment International 29: 1019-1028

525 Nascimento FJA, Lallias D, Bik HM, Creer S. 2018. Sample size effects on the assessment of 526 eukaryotic diversity and community structure in aquatic sediments using high-throughput 527 sequencing. Scientific Reports 8: 11737 DOI:10.1038/s41598-018-30179-1

528 Nóbrega GN, Ferreira TO, Romero RE, Marques AGB, Otero XL. 2013. Iron and sulfur 529 geochemistry in semi-arid mangrove soils (Ceará, Brazil) in relation to seasonal changes and $530 \quad$ shrimp farming effluents. Environmental Monitoring and Assessment 185: 7393-7407. $531 \quad$ https://doi.org/10.1007/s10661-013-3108-4 
532 Oksanen J, Blanchet FG, Kindt R, Legendre P. 2013. vegan: community ecology package. R

533 package version 20-10. https://cran.r-project.org/web/packages/vegan/ index.html.

534 Pedregosa F, Varoquaux G, Gramfort A, Michel V, Thirion B, Grisel O, Blondel M, Prettenhofer

535 P, Weiss R, Dubourg V, Vanderplas J, Passos A, Cournapeau D, Brucher M, Perrot M,

536 Duchesnay E. 2011. Scikit-learn: machine learning in Python. Journal of Machine Learning

$537 \quad$ Research 12: 2825-2830.

538 Quast C, Pruesse E, Yilmaz P, Gerken J, Schweer T, Yarza P, Peplies J, Glockner FO. 2013. The

539 SILVA ribosomal RNA gene database project: improved data processing and web-based

540 tools. Nucleic Acids Research 41(D1): D590-D596. https://doi.org/10.1093/nar/gks1219

541 Queiroz HM, Nobrega GN, Ferreira TO, Almeida LS, Romero TB, Santaella ST, Bernardino AF,

542 Otero JL. 2018. The Samarco mine tailing disaster: A possible time-bomb for heavy metals

543 contamination. Science of the Total Environment 637-638: 498-506

544 R Core Team, 2016. R: a Language and Environment for Statistical Computing. R Foundation

545 for Statistical Computing, Vienna, Austria. http://www.R-project.org/.

546 Rainbow PS. 2007. Trace metal bioaccumulation: Models, metabolic availability and toxicity.

547 2007. Environment International 33(4): 576-582. DOI: 10.1016/j.envint.2006.05.007

548 Venturini N, Muniz P, Rodriguez M. 2002. Macrobenthic subtidal communities in relation to

549 sediment pollution: the phylum-level meta-analysis approach in a south-eastern coastal

$550 \quad$ region of South America. Marine Biology 144: 119-126.

551 Xia D, Yi X, Lu Y, Huang W, Xie Y, Ye H, Dang Z, Tao X, Li L, Lu G. 2019. Dissimilatory

552 iron and sulfate reduction by native microbial communities using lactate and citrate as carbon

$553 \quad$ sources and electron donors. Ecotoxicology and Environmental Safety 174: 524-531.

$554 \quad$ https://doi.org/10.1016/j.ecoenv.2019.03.005 
555 Yin H, Tan N, Liu C, Wang J, Liang X, Qu M, Feng X, Qiu G, Tan W, Liu F. 2016. The

556 associations of heavy metals with crystalline iron oxides in the polluted soils around the

557 mining areas in Guangdong Province, China. Chemosphere 161: 181-189.

$558 \quad$ https://doi.org/10.1016/j.chemosphere.2016.07.018

559 
Figure 1

Map of the study site

Map of sediment sampling stations at the Rio Doce estuary, Brazil in August 2017 


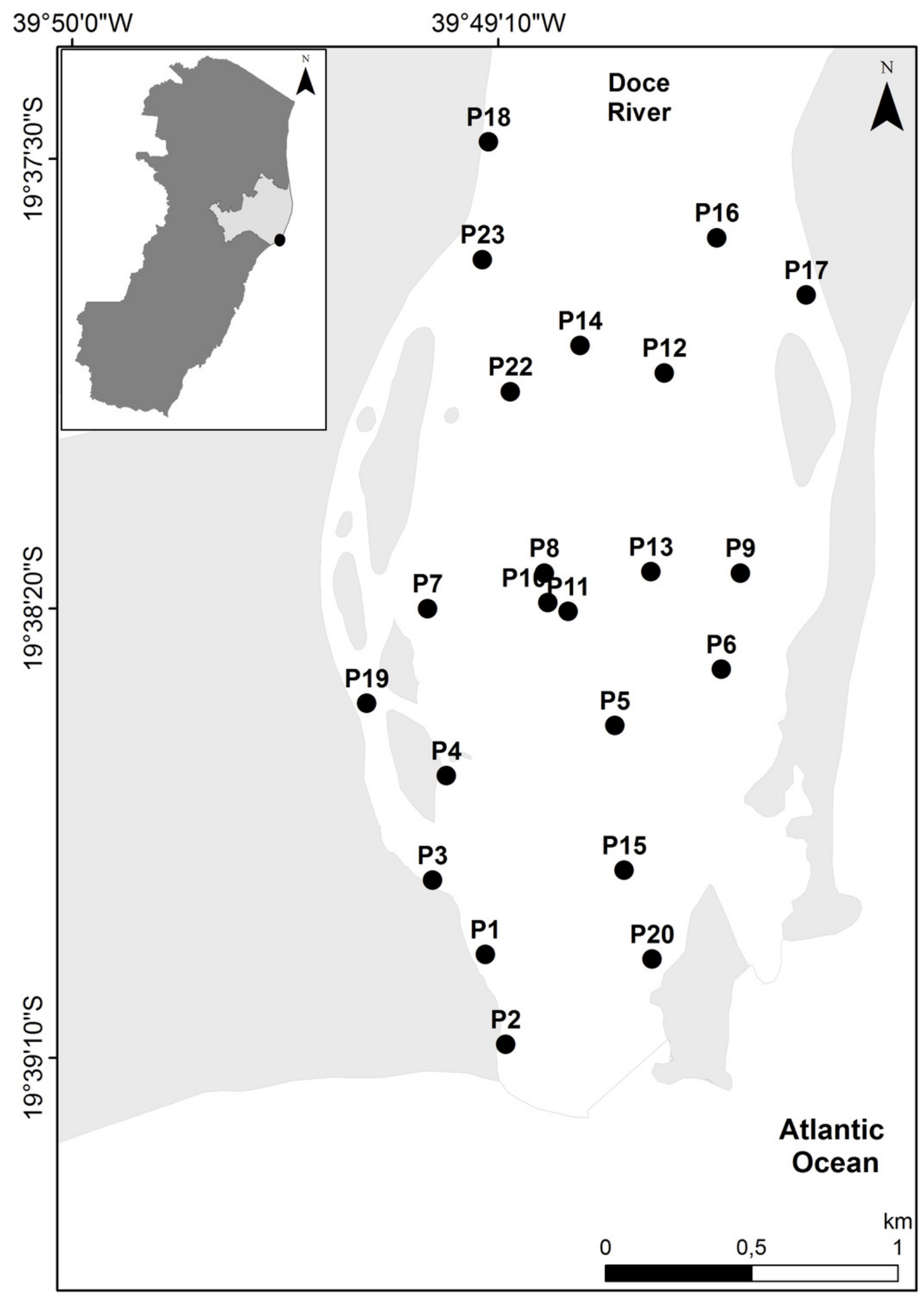


Figure 2

Benthic assemblage composition of the Rio Doce estuary

Benthic meiofaunal assemblage composition based on eDNA samples from the Rio Doce estuary in August 2017.

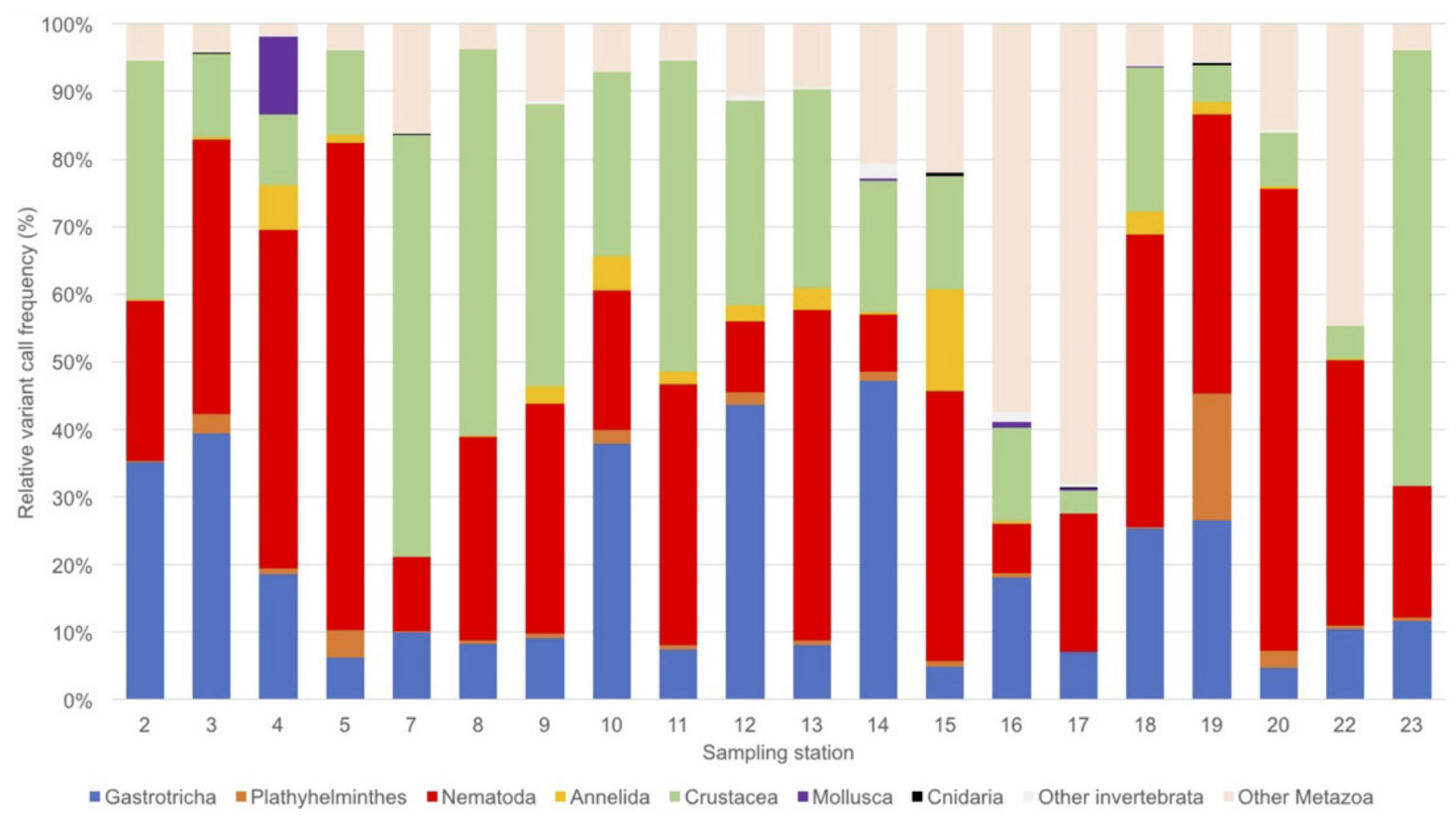


Figure 3

Taxa accumulation curves from eDNA samples

Taxa accumulation curves (Chaol index) based on full eOTU matrices (eDNA, blue dotted line), dominant eOTUS (>0.1\% sequence reads; eDNA_dom black dotted line) and on morphology-based macrofaunal pre-impact assessments (author's data published on Gomes et al., 2017) in the Rio Doce estuary. 


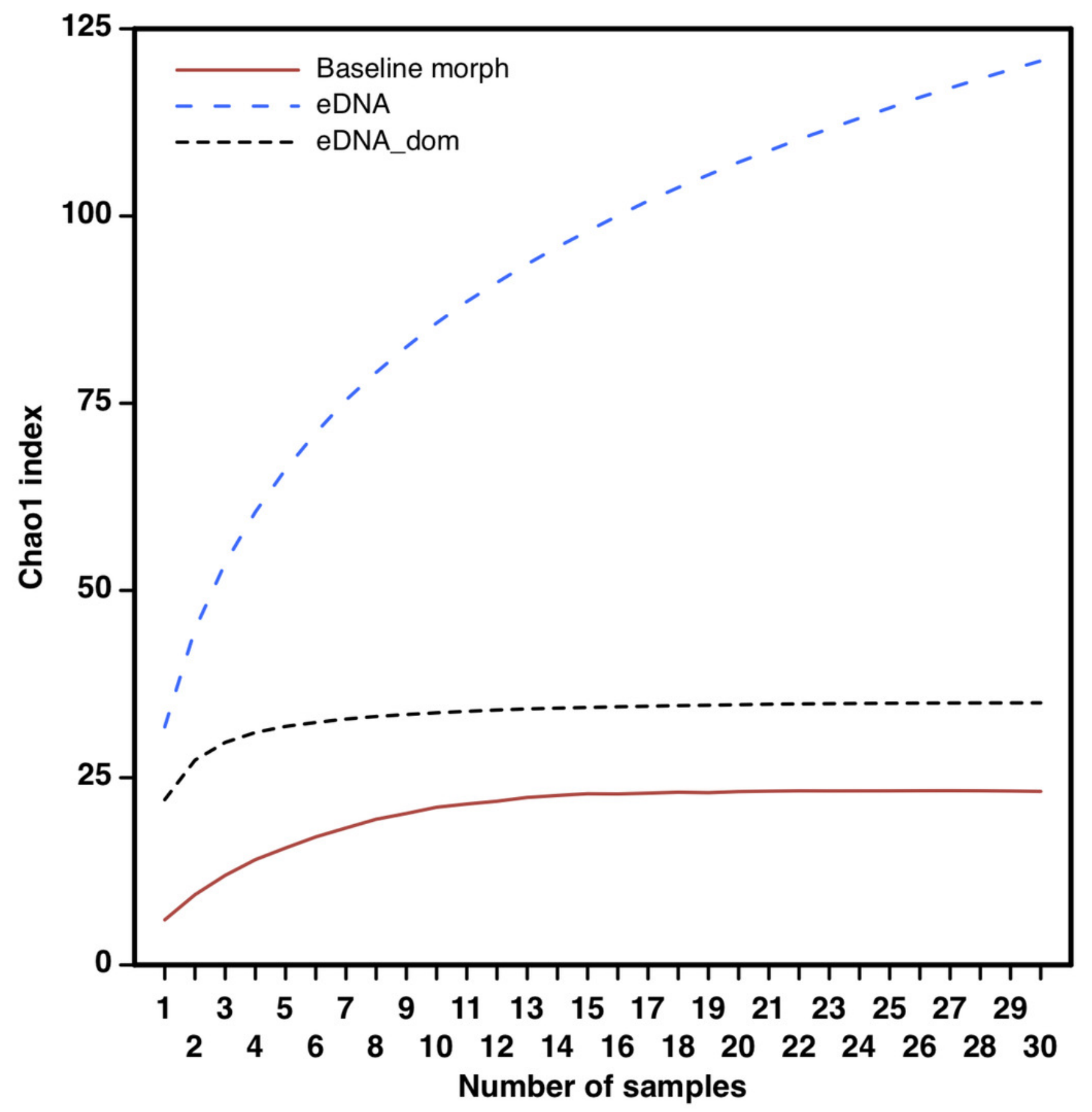


Figure 4

Correlation of eOTU richness with sediment Fe and TOM content

Correlation of eOTU richness with sediment Fe and TOM content across all sampling stations in the Rio Doce estuary in August 2017

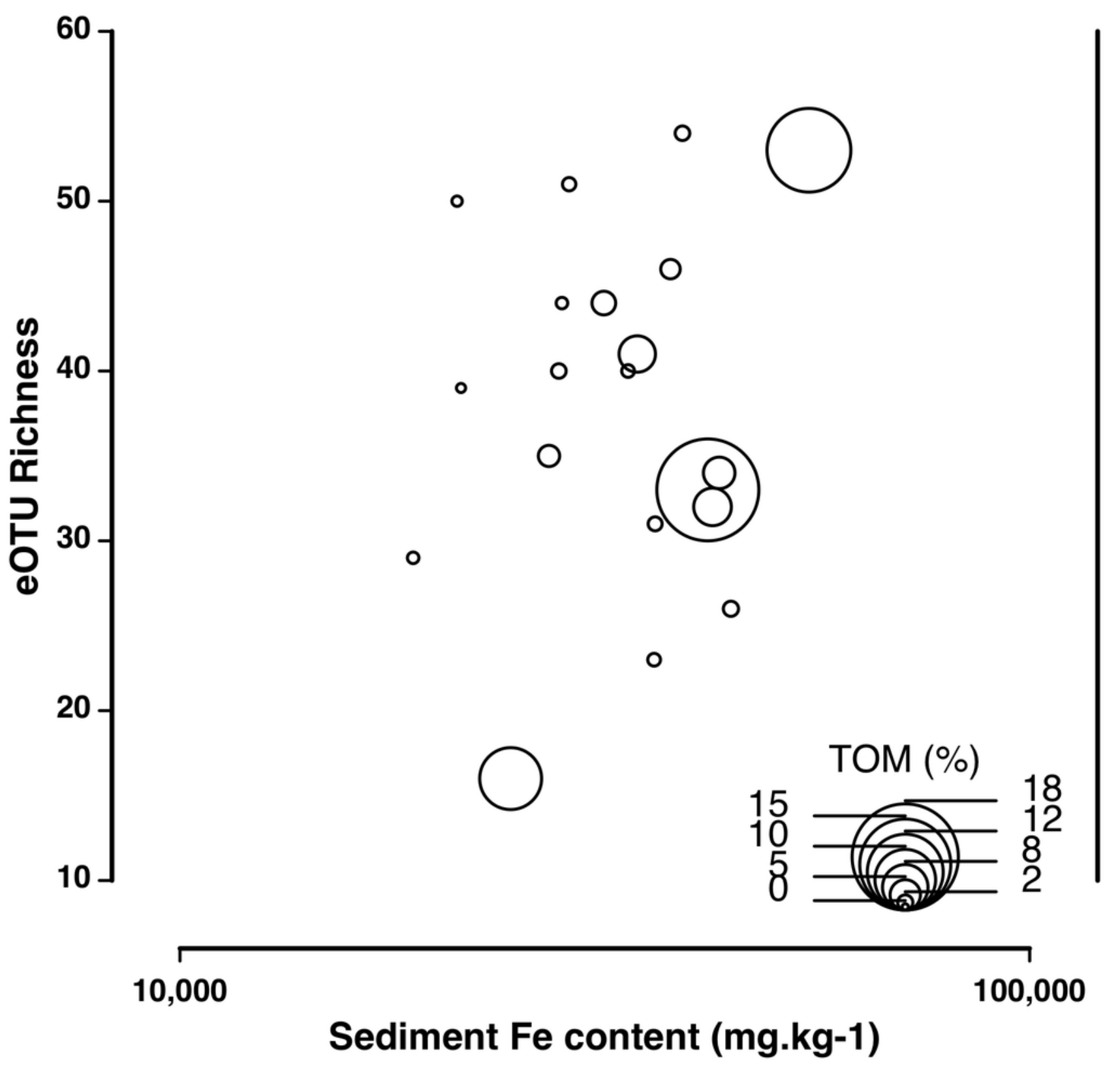




\section{Figure 5}

Multivariate analysis of assemblage composition and environmental filtering in the Rio Doce in August 2017

Canonical analyses of principal coordinates (CAP) ordination of samples according to multivariate distribution of dominant eOTUS (>0.1\% total SV reads) in the Rio Doce estuary. The strength and direction of environmental effects (Spearman correlation values with $p<$ 0.5 in red) on biological assemblages is represented by arrows of variable size.

Environmental variables were based on Table 1 ( $\mathrm{Fe}, \mathrm{Pb}, \mathrm{As}$, Salinity, TOM and \%Sand). Taxa scores indicate OTUs mostly correlated to site differences. Proportion of variance explained by axis 1 and 2 are in parenthesis. Symbol numbers indicate sampling station.

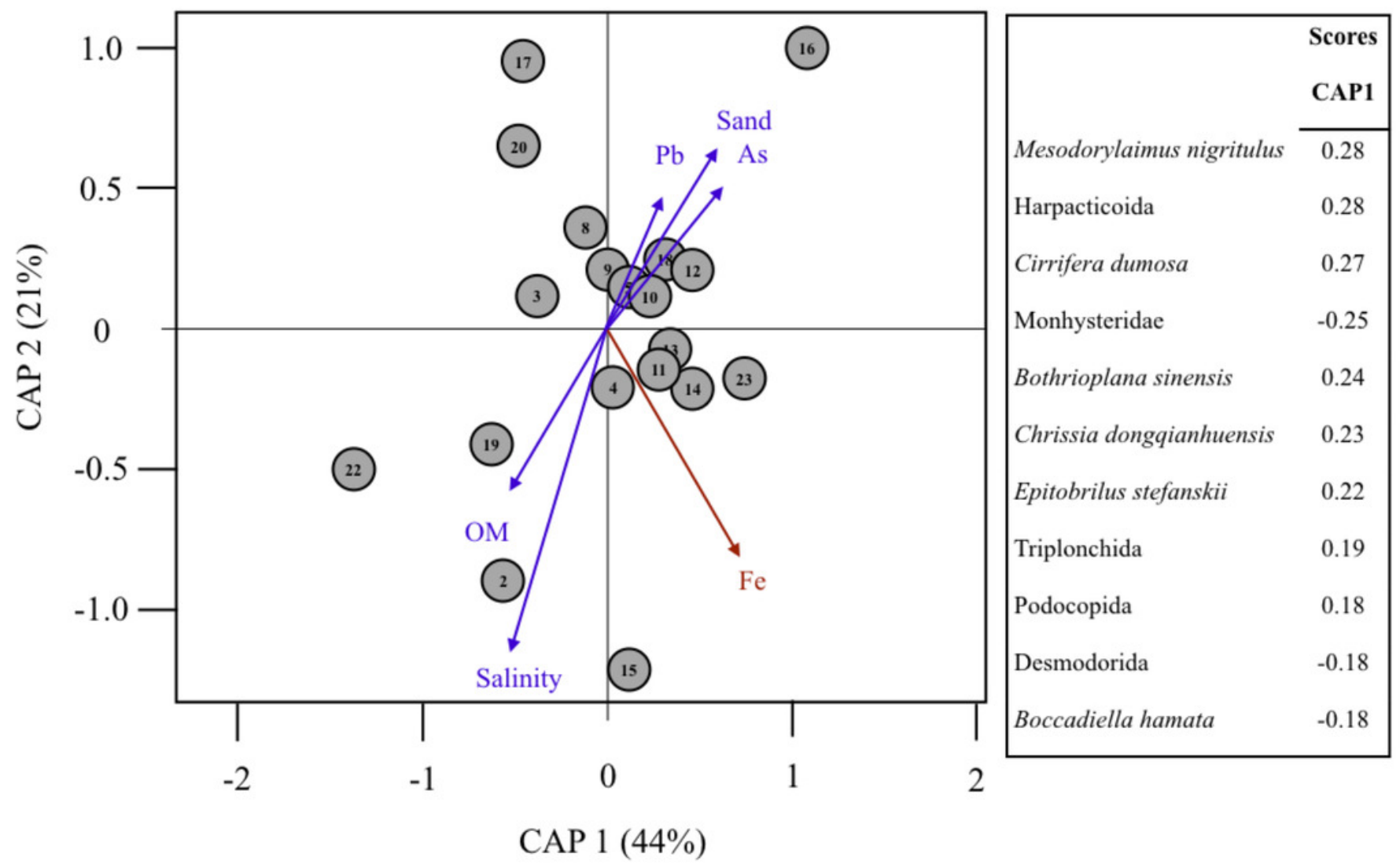




\section{Table $\mathbf{1}$ (on next page)}

Sediment, eDNA and environmental variables in the Rio Doce estuary

Salinity, Sediment total organic matter (TOM, \%), particle size (\% sand), concentration of trace metals ( $\mathrm{Fe}, \mathrm{As}$ and $\mathrm{Pb}$ ), and Number of sequence variant reads (reads $\mathrm{SV}$ ) and richness per station. All data sampled in August 2017 or 1.7 years after the Samarco disaster. Trace metals averaged from $\mathrm{N}=2$ replicates (SE). $\mathrm{N}$. number of eDNA replicate samples sequenced per station. Reads SV. Total marine/aquatic meiofaunal sequence variants. 
1 Table 1. Salinity, Sediment total organic matter (TOM, \%), particle size (\% sand), concentration 2 of trace metals ( $F e$, As and $\mathrm{Pb}$ ), and Number of sequence variant reads (reads $\mathrm{SV}$ ) and richness 3 per station. All data sampled in August 2017 or 1.7 years after the Samarco disaster. Trace metals 4 averaged from $N=2$ replicates (SE). $N$. number of eDNA replicate samples sequenced per station. 5 Reads SV. Total marine/aquatic meiofaunal sequence variants.

6

\begin{tabular}{|c|c|c|c|c|c|c|c|c|}
\hline $\begin{array}{l}\text { Station } \\
(\mathrm{N})\end{array}$ & $\begin{array}{l}\text { Salinit } \\
\mathbf{y}\end{array}$ & $\begin{array}{l}\text { TOM } \\
(\%) \\
\end{array}$ & $\begin{array}{l}\text { \%sa } \\
\text { nd }\end{array}$ & $\begin{array}{l}\mathrm{Fe} \\
\left.(\mathrm{mg.kg})^{-1}\right)\end{array}$ & $\begin{array}{l}\text { As } \\
\left(\mathrm{mg} \cdot \mathrm{kg}^{-1}\right)\end{array}$ & $\begin{array}{l}\text { Pb } \\
\left(\mathrm{mg} \mathrm{kg}^{-1}\right)\end{array}$ & $\begin{array}{l}\text { Reads } \\
\text { SV } \\
\end{array}$ & $\begin{array}{l}\text { Total SV } \\
\text { richness }\end{array}$ \\
\hline $2(2)$ & 1.0 & 6.2 & 12 & $\begin{array}{r}42,343 \\
(2,468) \\
41,808\end{array}$ & $2.3(0.1)$ & $56.9(4.8)$ & 256,072 & 32 \\
\hline $3(2)$ & 0.6 & 16.8 & 72 & $\begin{array}{l}(1,278) \\
33,681\end{array}$ & $10.1(14)$ & $\begin{array}{r}77.8(2.7) \\
173.3\end{array}$ & 265,363 & 33 \\
\hline $4(2)$ & 0.3 & 2.1 & 90 & $\begin{array}{l}(2,429) \\
28,710\end{array}$ & $4.5(1.6)$ & $\begin{array}{r}(7.8) \\
115.4\end{array}$ & 359,718 & 40 \\
\hline $5(2)$ & 0.3 & 2.2 & 95 & $\begin{array}{l}(3,686) \\
36,142\end{array}$ & $1.6(2.2)$ & $(2.8)$ & 293,669 & 51 \\
\hline $7(2)$ & 0.4 & 2.1 & 64 & $\begin{array}{r}(134) \\
21,419\end{array}$ & $0.1(0.2)$ & $\begin{array}{r}74.5(7.5) \\
134.8\end{array}$ & 101,127 & 23 \\
\hline $8(2)$ & 0.2 & 1.5 & 96 & $\begin{array}{l}(3,212) \\
28,155\end{array}$ & $\begin{array}{r}0.1(0) \\
28.8\end{array}$ & $\begin{array}{r}(5.8) \\
111.4\end{array}$ & 238,735 & 39 \\
\hline $9(2)$ & 1.0 & 1.9 & 91 & $\begin{array}{l}(1,391) \\
27,184\end{array}$ & $(34.3)$ & $(40.7)$ & 254,335 & 44 \\
\hline $10(2)$ & 0.2 & 3.5 & 89 & $\begin{array}{r}(227) \\
43,116\end{array}$ & $0.1(0)$ & $83.1(5.9)$ & 226,548 & 35 \\
\hline $11(2)$ & 0.2 & 5.2 & 70 & $\begin{array}{r}(2,768) \\
39,029\end{array}$ & $\begin{array}{r}0.1(0) \\
13.3\end{array}$ & $\begin{array}{r}67.3(4.3) \\
174.4\end{array}$ & 272,299 & 34 \\
\hline $12(1)$ & 0.1 & 2.4 & 84 & $\begin{array}{r}(11,713) \\
54,983\end{array}$ & (16.2) & $\begin{array}{r}(28) \\
117.3\end{array}$ & 132,722 & 54 \\
\hline $13(2)$ & 0.2 & 13.8 & 91 & $\begin{array}{l}(4,157) \\
27,920\end{array}$ & $3.9(5.5)$ & $\begin{array}{r}(12.9) \\
30.3\end{array}$ & 236,707 & 53 \\
\hline $14(1)$ & 1.6 & 2.4 & 86 & $\begin{array}{l}(7,793) \\
34,532\end{array}$ & $\begin{array}{r}0.1(0) \\
16.7\end{array}$ & (11.8) & 71,648 & 40 \\
\hline $15(2)$ & 3.7 & 6 & 85 & $\begin{array}{l}(1,980) \\
31,539\end{array}$ & $(15.6)$ & $78.2(4.6)$ & 320,192 & 41 \\
\hline $16(1)$ & 0.3 & 3.9 & 90 & $\begin{array}{l}(1,001) \\
21,191\end{array}$ & $0.0(0)$ & $\begin{array}{r}33.1(2.1) \\
192.9\end{array}$ & 35,915 & 44 \\
\hline $17(2)$ & 0.1 & 1.7 & 90 & $\begin{array}{r}(42) \\
37,781\end{array}$ & $2.1(0.2)$ & $\begin{array}{r}(15.1) \\
160.8\end{array}$ & 54,355 & 50 \\
\hline $18(2)$ & 0.2 & 3.2 & 88 & $\begin{array}{l}(1,120) \\
36,244\end{array}$ & $11.2(2.7)$ & $\begin{array}{r}(6.2) \\
118.0\end{array}$ & 222,481 & 46 \\
\hline $19(1)$ & 0.4 & 2.3 & 93 & $\begin{array}{r}(801) \\
18,814\end{array}$ & $3.7(0.5)$ & $(3.5)$ & 103,987 & 31 \\
\hline $20(1)$ & 1.9 & 1.9 & 62 & $\begin{array}{r}(94) \\
24,501\end{array}$ & $0.1(0)$ & $14.2(1.5)$ & 139,712 & 29 \\
\hline $22(1)$ & 1.3 & 10.2 & 91 & $\begin{array}{r}(3,804) \\
44,506\end{array}$ & $0.1(0)$ & $16.0(6.9)$ & 69,713 & 16 \\
\hline $23(1)$ & 0.3 & 2.5 & 89 & $(1,079)$ & $4.9(2.2)$ & $99.1(7.6)$ & 133,700 & 26 \\
\hline
\end{tabular}

8 


\section{Table 2 (on next page)}

Results of the canonical analysis of principal coordinates

Results of the Canonical Analysis of Principal coordinates (CAP) testing the contribution of sediment (TOM\%, sand content), water salinity and concentrations of trace metals in sediments ( $\mathrm{As}, \mathrm{Fe}, \mathrm{Pb}$ ) to the multivariate distribution of meiofaunal (eDNA) assemblages in the samples from Rio Doce estuary. Spearman correlation values for each sediment variable are described for in CAP axis 1-2. Note: proportion of variability explained by CAP axes are highlighted, F for statistic, significant results $(p<0.05)$ are in bold. 
1 Table 2. Results of the Canonical Analysis of Principal coordinates (CAP) testing the 2 contribution of sediment (TOM\%, sand content), water salinity and concentrations of trace 3 metals in sediments ( $\mathrm{As}, \mathrm{Fe}, \mathrm{Pb}$ ) to the multivariate distribution of meiofaunal (eDNA) 4 assemblages in the samples from Rio Doce estuary. Spearman correlation values for each 5 sediment variable are described for in CAP axis 1-2. Note: proportion of variability explained by 6 CAP axes are highlighted, $F$ for statistic, significant results $(p<0.05)$ are in bold.

7

\begin{tabular}{lccccccccc}
\hline & \multicolumn{3}{c}{ All eOTUS $(\mathrm{N}=123)$} & \multicolumn{5}{c}{ Dominant eOTUS (N=32) } \\
& axis1 & axis2 & $\mathrm{F}$ & $p$ & axis1 & axis2 & $\mathrm{F}$ & $p$ \\
& 0.33 & 0.29 & & & 0.44 & 0.21 & & \\
& -0.63 & 0.09 & 1.24 & 0.223 & -0.30 & -0.71 & 1.60 & 1.77 \\
Salinity & -0.55 & -0.18 & 0.89 & 0.485 & -0.33 & -0.36 & 0.71 & 0.592 \\
$\mathrm{OM}$ & 0.71 & 0.26 & 1.01 & 0.413 & 0.37 & 0.40 & 1.17 & 0.272 \\
$\mathrm{Sand}$ & 0.02 & 0.26 & 0.63 & 0.815 & 0.39 & 0.31 & 0.79 & 0.506 \\
$\mathrm{As}$ & -0.29 & 0.46 & 1.45 & 0.135 & 0.43 & -0.51 & 2.89 & $\mathbf{0 . 0 1 8}$ \\
$\mathrm{Fe}$ & 0.70 & -0.08 & 1.11 & 0.303 & 0.19 & 0.28 & 1.59 & 0.160 \\
$\mathrm{~Pb}$ & & & & & & & & &
\end{tabular}

8

9

10 